\title{
New species of many-plumed moth (Lepidoptera: Alucitidae) from the Democratic Republic of Congo
}

\author{
Новые виды веерокрылок (Lepidoptera: Alucitidae) \\ из Аемократической Респубцики Конго
}

\author{
P.Ya. Ustjuzhanin ${ }^{1,2 *}$, V.N. Kovtunovich ${ }^{3}$, A.N. Streltzov ${ }^{4}$ \\ П.Я. Устюжканин ${ }^{1,2 *}$, В.Н. Ковтунович, ${ }^{3}$ А.Н. Стрельцов ${ }^{4}$
}

\footnotetext{
${ }^{1}$ Altai State University, Lenina 61, Barnaul 656049, Russia. E-mail: petrust@mail.ru

${ }^{2}$ Biological Institute, Tomsk State University, Lenina Prospekt 36, Tomsk 634050, Russia.

${ }^{3}$ Moscow Society of Nature Explorers, Bolshaya Nikitskaya 2, Moscow 125009, Russia. E-mail: vasko-69@mail.ru

${ }^{4}$ Herzen State Pedagogical University of Russia, Moika Emb. 48, St-Petersburg 191186, Russia. E-mail: streltzov@mail.ru

${ }^{1}$ Алтайский государственный университет, пр. Ленина 61, Барнаул 656049, Россия.

2 Томский государственный университет, институт биологии, пр. Ленина 36, Томск 634050, Россия.

${ }^{3}$ Московское общество испытателей природы, ул. Большая Никитская 6, Москва 103009, Россия.

${ }^{4}$ Российский государственный педагогический университет имени А. И. Герцена, наб. реки Мойки 48, Санкт-Петербург 191186 Россия. *Corresponding author
}

KEY WORDS: Alucitidae, many-plumed moths, the Democratic Republic of Congo, Katanga, new species, new data.

КЛЮЧЕВЫЕ СЛОВА: Alucitidae, Веерокрылки, Демократическая Республика Конго, Катанга, новые виды, новые данные.

ABSTRACT. Two species of Alucitidae, new to science, Alucita romieuxi Ustjuzhanin et Kovtunovich sp.n. and Alucita katanga Ustjuzhanin et Kovtunovich sp.n., are described from the Democratic Republic of Congo; three species, Alucita compsoxantha (Meyrick, 1924), A. ectomesa (Hering, 1917) and A. tesserata (Meyrick, 1918) are reported as new to the fauna of the country.

РЕЗЮМЕ. Из Демократической Республики Конго, описываются два новых вида веерокрылок: Alucita romieuxi Ustjuzhanin et Kovtunovich sp.n. и Alucita katanga Ustjuzhanin et Kovtunovich sp.n., и три вида: Alucita compsoxantha (Meyrick, 1924), A. tesserata (Meyrick, 1918) и A. ectomesa (Hering, 1917) приводятся как новые для фауны данной страны.

\section{Introduction}

Many-plumed moths of the Democratic Republic of Congo are extremely poorly studied. The first information on them appeared after the release of catalogue of Lepidoptera of Belgian Congo [Ghesquière, 1940]. This publication described a new species, Orneodes fletcheriana Ghesquière, 1940, Alucita huebneri Wallengren, 1859 was reported, and three indefinite species were indicated as Orneodes sp. In the online database of Afrotropical moths species [De Prins, De Prins, 2020] the species Alucita phanerarcha (Meyrick, 1924) was reported for the Democratic Republic of Congo. Among the materials provided for our research by Dr. Bernard Landry from Muséum d'histoire naturelle de Genève (MHNG) we indicated two species new to science: Alucita romieuxi Ustjuzhanin et Kovtunovich sp.n. and Alucita katanga Ustjuzhanin et Kovtunovich sp.n., and two species, Alucita compsoxantha (Meyrick, 1924) and Alucita tesserata (Meyrick, 1918) were indicated for the fauna of the Democratic Republic of Congo for the first time.

Abbreviations: CUK - The collection by P. Ustjuzhanin and V. Kovtunovich (Novosibirsk and Moscow, Russia); MHNG - Muséum d'histoire naturelle de Genève, Switzerland.

\section{Taxonomy}

Alucita compsoxantha (Meyrick, 1924)

Orneodes compsoxantha Meyrick, 1924: 95. (Type locality: Mazoe [Zimbabwe], S. Rhodesia).

MATERIAL EXAMINED. Ht Katanga, Tshinkolobwe, $10^{7}$, 27.XI.[19]30, 1 O$^{7}$, 10. XII.[19]30, J. Romieux leg. (MHNG gen.pr. 202001, 202002)

DISTRIBUTION: Zimbabwe, Malawi [Ustjuzhanin, Kovtunovich, 2016], Democratic Republic of Congo. NOTE. New to the Democratic Republic of Congo.

How to cite this article: Ustjuzhanin P.Ya., Kovtunovich V.N., Streltzov A.N. 2020. New species of manyplumed moth (Lepidoptera: Alucitidae) from the Democratic Republic of Congo // Russian Entomol. J. Vol.29. No.2. P.199-202. doi: 10.15298/rusentj.29.2.13 


\section{Alucita ectomesa (Hering, 1917)}

Orneodes ectomesa Hering, 1917: 190. (Type locality: N. Nyasa, Tanzania).

Orneodes myriodesma Meyrick, 1929: 533. (Type locality: Makulane, [Mozambique]).

MATERIAL EXAMINED. Ht Katanga, Tshinkolobwe, $1+24$. IX. [19]31, 1우 09.X. [19]31, J. Romieux leg. (MHNG gen.pr. 202003 , 202004).

DISTRIBUTION: Tanzania [Hering, 1917]; Malawi, Mozambique [De Prins, De Prins, 2020], Rep. S. Africa [Ustjuzhanin, Kovtunovich, 2017], Democratic Republic of Congo.

NOTE. New to the Democratic Republic of Congo.

\section{Alucita tesserata (Meyrick, 1918)}

Orneodes tesserata Meyrick, 1918: 34. (Type locality: Pretoria, Republic of South Africa).

Orneodes brachyzona Meyrick, 1920: 293. (Type locality: Abraham's Kraal, Free State, Rep. S. Africa).

MATERIAL EXAMINED. Ht Katanga, Tshinkolobwe, 2 ex, 16-23.XII. [19]30, J. Romieux leg.

DISTRIBUTION: Republic of South Africa, Zimbabwe, Malawi [De Prins, De Prins 2020], Democratic Republic of Congo.

NOTE. New to the Democratic Republic of Congo.

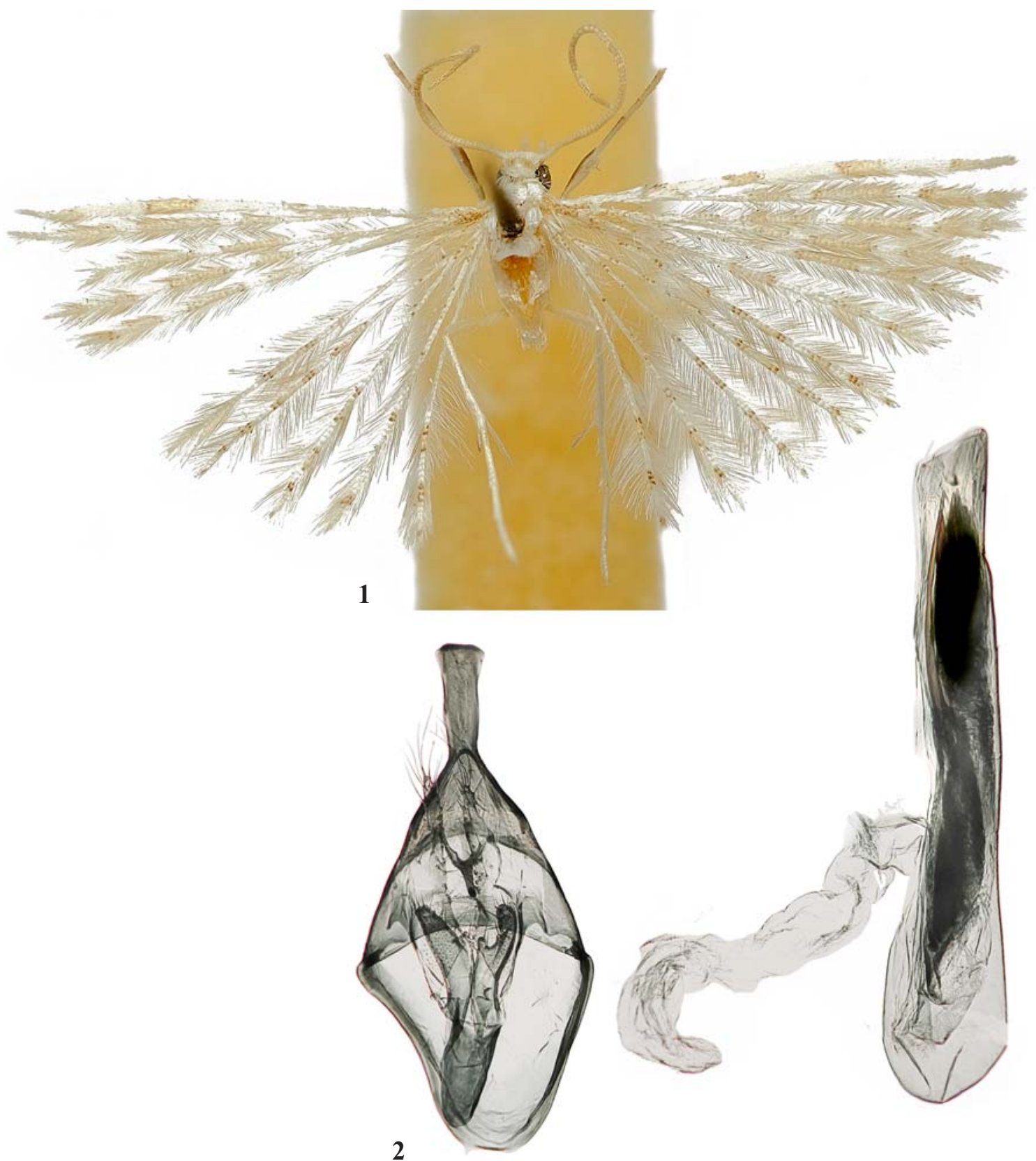

Figs 1-2. Alucita romieuxi, sp.n.: 1 - adult, male, holotype; 2 - male genitalia, holotype (MHNG gen.pr. 202005).

Pис. 1-2. Alucita romieuxi, sp.n.: 1 - имаго, самец, голотип; 2 - гениталии самца, голотип (MHNG gen.pr. 202005). 


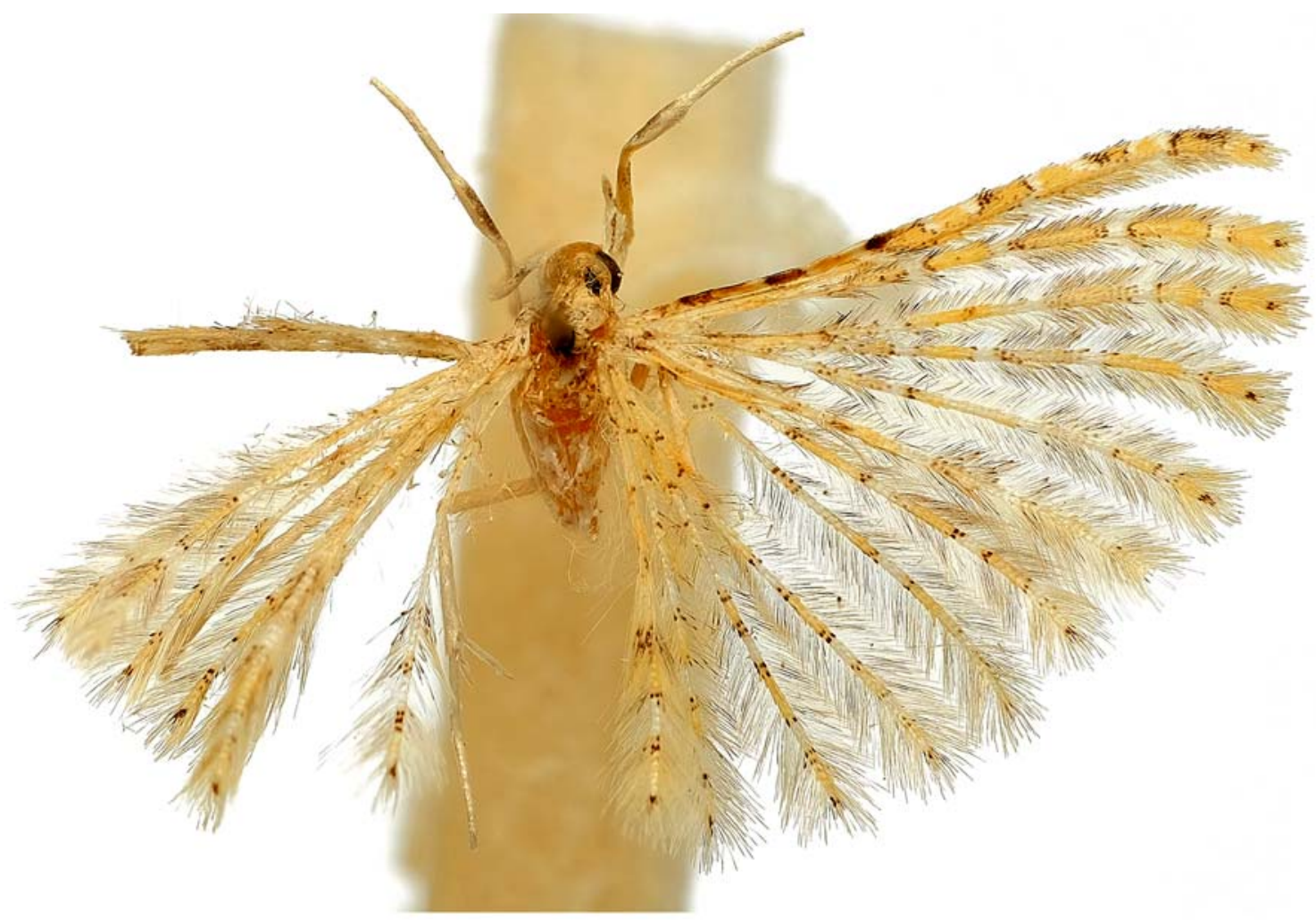

3
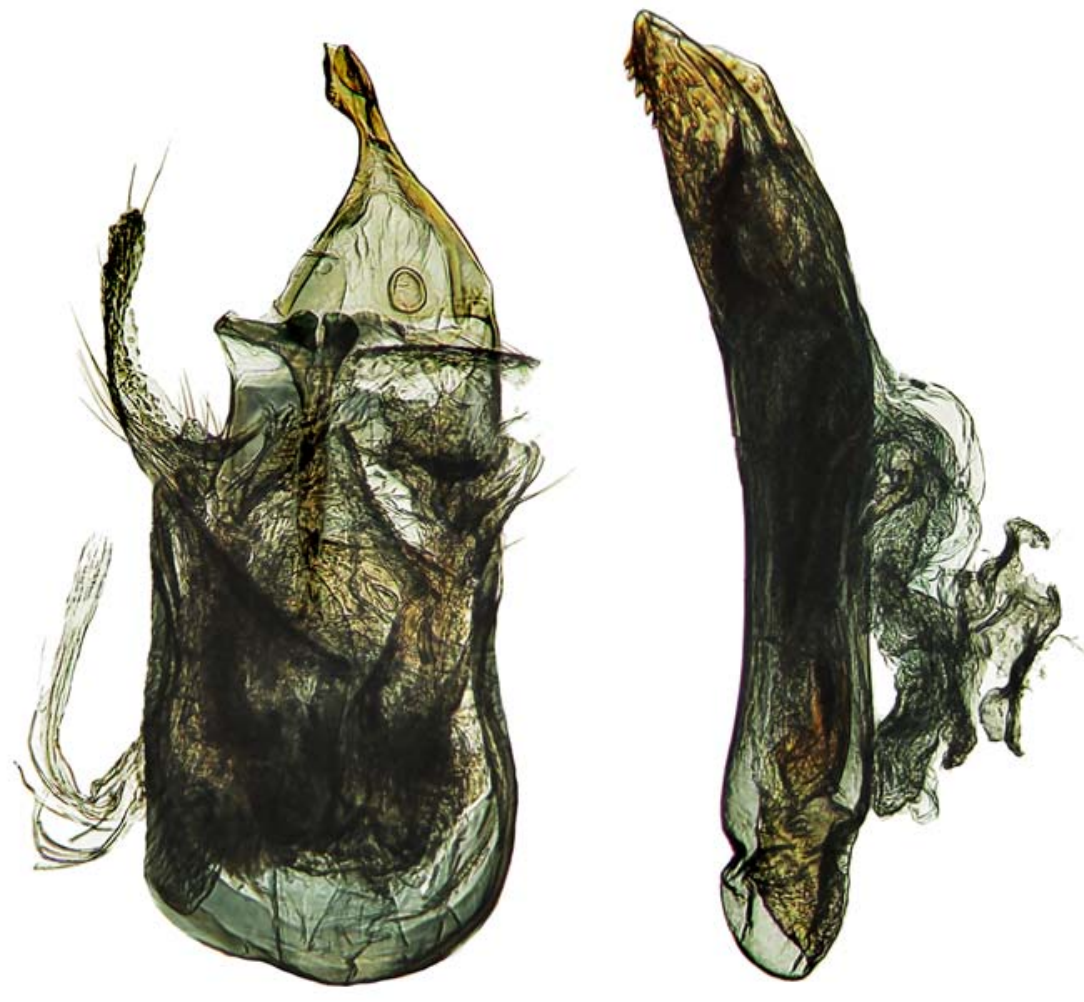

4

Figs 3-4. Alucita katanga, sp.n.: 3 - adult, male, holotype; 4 - male genitalia, holotype (MHNG gen.pr. 202006).

Рис. 3-4. Alucita katanga, sp.n.: 3 - имаго, самец, голотип; 4 - Гениталии самца, голотип (MHNG gen.pr. 202006). 


\section{Alucita romieuxi Ustjuzhanin et Kovtunovich, sp.n. Figs 1-2.}

TYPE MATERIAL. Holotype, ơ, (MHNG gen.pr. 202005), Democratic Republic of Congo, Ht Katanga, Tshinkolobwe, 25.I. [19]31, J. Romieux leg.

DESCRIPTION: External characters (Fig. 1). Head, thorax and tegula white. Antenna light grey. Labial palpus white, twice longer than longitudinal eye diameter, directed forward and slightly up, second segment interspersed with grey scales. Wingspan $10 \mathrm{~mm}$. Wings snow-white, longitudinal light brown portions of scales along lobes of all wings. These portions longer and more contrast on fore wing, shorter and less contrast on hind wing. Fringe of white hairs. Hind leg white.

Male genitalia (Fig. 2). Uncus evenly wide, apically flat. Gnathos short, thin, apically uncinately curved. Valve narrow, membranous. Anellus arms short, wide. Saccus arched. Aedeagus robust, slightly longer than all genital structure, with two large spiky cornuti.

Female unknown.

DIAGNOSIS. In the white colour of the wings and in the longitudinal brown portions of scales on the lobes, the new species resembles to Alucita snezhinka Ustjuzhanin \& Kovtunovich, 2018, but differs in the less contrast light brown portions of scales which are short on the hind wings. In the male genital structure, the new species is close to Alucita crococyma (Meyryck, 1937) in the similar shape of the uncus. In the large aedeagus exceeding all the genital apparatus, the new species is similar to $A$. snezhinka, but differs in the uncus and gnathos structure, and in the anellus arms.

FLIGHT PERIOD: January.

ETYMOLOGY. The species is named after the Swiss entomologist Jean Romieux (1893-1951), who collected its specimens.

\section{Alucita katanga Ustjuzhanin et Kovtunovich, sp.n. Figs 3-4.}

TYPE MATERIAL. Holotype, ơ, (MHNG gen.pr. 202006), Democratic Republic of Congo, Ht Katanga, Panda, 11.XI. [19]29, J. Romieux leg.

DESCRIPTION: External characters (Fig. 3). Head, thorax and tegula yellow-brown. Labial palpus yellow-brown, twice longer then longitudinal eye diameter, directed forward and up, third segment apically sharp. Wingspan $12 \mathrm{~mm}$. Wings yellow, with transverse, poorly noticeable white bands. Dark brown spots and strokes on costal edge of first lobe of fore wing. All lobes apically ending with small brown spot. Hind wings lighter than fore wings, with less expressed brown apical spots of lobes. Fringe on wings with alternating light brown and white portions. Antenna yellow-brown.
Male genitalia (Fig. 4). Uncus narrow, rhomboid, apically flat. Gnathos narrow, long, distally tapered. Valves narrow, membranous. Saccus wide, arched. Aedeagus robust, equal to all genital structure in length, with three large spiky cornuti, aedeagus apically serrated.

Female unknown.

DIAGNOSIS. In the wings colour, similar to Alucita aarviki Ustjuzhanin et Kovtunovich, 2016, but differs in the brown spots on the lobes apically and in the dark brown strokes and spots along the costal edge of the first lobe on the fore wing. Concerning the male genitalia, there are no similar species among the African many-plumed moths.

FLIGHT PERIOD: November.

ETYMOLOGY. Toponymic name.

Only two species were previously known for the fauna of Congo; our research has added five more species, two of which proved to be new to science. Undoubtedly, for one of the biggest African countries, the Democratic Republic of Congo, with its richness and diversity of natural landscapes, the fauna of many-plumed moths must counter up to 30 species.

Acknowledgements. The authors express their deep gratitude to Dr. Bernard Landry (Genève, Switzerland) for providing the Alucitidae specimens for our research, and to Sergey Reshetnikov (Novosibirsk, Russia) for providing photos of the adults.

\section{References}

De Prins J., De Prins W. 2018. Afromoths. An online database of Afrotropical moths species (Lepidoptera). Available from: http:/ /www.afromoths.net (accessed 11 February 2020).

Ghesquière J. 1940. Lépidoptères Microlépidoptères (première partie) // Annales du Musée du Congo belge, Zoologie [3, Arthropodes] Section 2. Catalogues raisonnés Sér. III (II). Vol.7. No.1. P.1-120. Pl.vi.

Hering E.M. 1917. Sieben neue Arten der Gattung Orneodes // Stettiner Entomologische Zeitung. Bd.78. S.190-195.

Meyrick E. 1918. Descriptions of South African Micro-Lepidoptera // Annals of the Transvaal Museum. Vol 6. No.2. P.7-59.

Meyrick E. 1920. Voyage de Ch. Alluaud et R. Jeannel en Afrique Orientale (1911-1912) // Résultats Scientifiques. Insectes Lépidoptères II. Microlepidoptera. P.33-120.

Meyrick E. 1924. Exotic Microlepidoptera 3. Vol.3. No.3-4. P.65-128.

Ustjuzhanin P.Y., Kovtunovich V.N. 2016. The Alucitidae (Lepidoptera) of Malawi with descriptions of five new species // Zootaxa. Vol.4126. No.4. P.533-547.

Ustjuzhanin P., Kovtunovich V. 2017. Many-plumed moths of the republic of South Africa (Lepidoptera, Alucitidae) // Ukrainian Journal of Ecology. Vol.7. No.4. P.640-643. 